\title{
UK Parliamentary panel calls for human genetics authority
}

civil power plant in an emergency.

Anti-nuclear groups are more direct. "This is 75 per cent a 'pork barrel' issue particularly in South Carolina, where they are scrambling for any jobs programme they can find," says Tom Clements of Greenpeace.

The accelerator would use a high-power version of LANSCE, the existing linear protons into a target, producing neutrons which in turn would convert lithium-3 gas into tritium. "The accelerator has a lower capital cost than the reactors, but higher operating costs," says Paul Lisowski, head of the Accelerator Production of Tritium (APT) office at Los Alamos, who admits it would consume a vast amount of electricity $-350 \mathrm{MW}$, enough for a city of a third of a million people.

Critics say the technology is untried. But reviews by various groups, including a Jason panel chaired by Sidney Drell, the Stanford physicist, have said that it will work. According to Lisowski, the research phase would establish the best target materials, and use a prototype of the front section of the accelerator to iron out any problems with dispersal of such a high-power beam.

Physicists, who were recently deprived of a proposed advanced neutron source of their own (see Nature 373, 460; 1995), are now likely to pursue changes in the APT project that would allow it to be used for experiments.

Earlier this year, for example, Burt Richter, director of the Stanford Linear Accelerator Center (SLAC), suggested this idea to Martha Krebs and Vic Reis, the assistant secretaries in charge of energy research and nuclear weapons.

In a letter to the two officials, Richter argued that changes costing "a few hundred million dollars" could provide the United States with "the world's premier spallation source" of neutrons. He also pointed out that, subject to future arms control agreements, tritium may not be needed in the quantities envisaged.

Krebs rejected Richter's plan on both technical and financial grounds. But laboratory officials say that O'Leary's decision to proceed with the accelerator may revive it, and observers feel that the DOE's real problem is its historical aversion to joint civil-military facilities. Colin Macilwain proton accelerator at Los Alamos, to drive

London. In a wide-ranging report that is likely to have a major impact on government policies in both Britain and elsewhere, a committee of the UK House of Commons has recommended the creation of a statutory body with broad responsibilities to regulate the applications of human genetics.

The activities of such a body - which it suggests should be called the Human Genetics Commission - would range from advising local ethics committee on research involving genetic screening, to regulating companies offering genetic services.

The committee has also proposed reforms in the way the patent system is applied to genetic information which would, it hopes, maintain the benefits of the system while limiting its potential for abuse.

In particular, while accepting that human gene sequences should remain patentable, it suggests that patent protection should be restricted to a particular application of the sequence - and that the discoverer of a separate application should be eligible for a separate patent.

The recommendations have emerged from an intense eight-month study by the House of Commons Select Committee on Sci- UNAVAILABLE ence and Technology, which attracted 161 submissions, and involved over 12 public hearings.

Sir Giles Shaw,

Conservative Mem- Shaw: issues warrant a ber of Parliament regulatory system. for Pudsey and chairman of the committee, says the recommendation to set up a statutory genetics authority was a further step along a path that had already involved the creation of advisory bodies such as the Gene Therapy Advisory Committee.

"The scale of the issue raised by the application of genetic science, ranging from questions about patents to the behaviour of

\section{FDA approval allows gene therapy in Japan}

Tokyo. The US Food and Drug Administration (FDA) has opened the way for the first clinical application of gene therapy in Japan. Last week, the agency approved the export to Japan of a retroviral vector developed by the US National Institutes of Health and the company Genetic Therapy Inc. (GTI).

Supplies of the vector are due to be shipped this week, and will be used a few days after arrival by a group at Hokkaido
University to treat a 4-year-old boy suffering from adenosine deaminase (ADA) deficiency, an enzyme deficiency that weakens the immune system.

The Japanese government approved this first application of gene therapy in February. But the Hokkaido group has been almost entirely dependent on US technology for the technique, and had to await FDA approval for the export of GTI's product.
David Swinbanks the insurance industry, is, in our judgement, sufficient to warrant a comprehensive regulatory system," Shaw said this week.

The report itself points out that Virginia Bottomley, the former health secretary, recently promised that the government would consult widely on the setting up of a non-statutory committee (see Nature 375, 714; 1995). But it adds: "we consider that such consultation has been carried out in the course of this enquiry".

It points out that a "substantial" number of the individuals and organizations that it had consulted supported calls for a regulatory body not only to cover genetic screening - as proposed in an earlier report from the Nuffield Council on Bioethics - but "with wider terms of reference to oversee developments in genetics science."

Reflecting the broad spectrum of political views among the committee's 11 members, concern over the potential misuse of genetic information by insurance companies is tempered by reluctance to impose rigid rules of behaviour. Thus the select committee would give the insurance industry a year in which to propose a form of regulation acceptable to Parliament; only if it fails to do so would a solution be sought by legislation.

But merely highlighting such concern will reinforce calls from pressure groups for government action. Already the Genetics Interest Group, for example, which represents a coalition of medical action groups, has announced plans to use the report to back an amendment to disability legislation currently being debated in the House of Lords; this would give the government powers to act against those found guilty of "genetic discrimination" in employment.

The committee comes down firmly against patents on fragments of genes or on genes of no known function. It also insists that the principle of the exclusion from patentability on the grounds of morality as stated in the European Patent Convention - should remain.

Its proposed compromise on individual gene sequences is that a combination of a gene and a known, novel and unobvious utility should be patentable "in the context of that utility" - while at the same time "a combination of the same gene and a further novel utility should also be patentable."

Such a formula, committee members hope, both acknowledges the validity of gene patents and restricts the breadth of their potential application, and will thus be attractive to those seeking to resolve conflict. "I hope our report will reassure those colleagues who remain unhappy about the issue of gene patents," says committee member Lynne Jones.

David Dickson 